\title{
Research
}

\section{State-Led Ecotourism Development and Nature Conservation: a Case Study of the Changbai Mountain Biosphere Reserve, China}

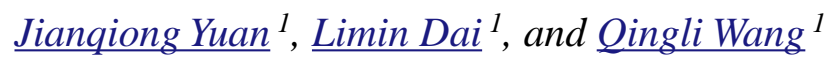

\begin{abstract}
Faced with fiscal constraints and enormous population pressures, $80 \%$ of Chinese nature reserves have employed ecotourism as a support and development strategy. Assessing the actual effects of ecotourism at a nature reserve that has a relatively long history of ecotourism development experience may be instructive for other reserves. Therefore, we take Changbai Mountain Biosphere Reserve (CMBR) in northeastern China as a case study, for it is one of the pioneers in embracing ecotourism in China. Personal interviews and informal group discussions were employed to understand local residents' attitudes toward conservation. Factors affecting their attitudes were then analyzed using logistic regression. Results indicate that attitudes held by most farmers are not favorable toward the conservation of the CMBR. It is not ecotourism but rather income from collection of forest products, household crop lands, and migrant labor that actually influences their attitudes. We found that the 1-day-sightseeing tour style, the limited tourism period, and the low level of education and extreme poverty of the local residents, together with existing institutions and lagging regulations make it very difficult for ecotourism to engender local residents' support. We concluded that institutional measures to guarantee local people's sharing in the revenue generated by the reserve, as well as regulations to ensure involvement of the local community in the decision-making process are preconditions for ecotourism to engender local support in China. Providing educational opportunities for children and vocational training for young local residents can also contribute indirectly to enhanced conservation.
\end{abstract}

Key Words: Changbai Mountain Biosphere Reserve; conservation; ecotourism; local support

\section{INTRODUCTION}

China's first nature reserve was established in 1956. As of 2006, 2395 nature reserves have been established in the country, accounting for $15.16 \%$ of its territory. In this way, $85 \%$ of China's terrestrial ecosystems, $85 \%$ of its wild animal populations, and $65 \%$ of the country's wild vegetation communities are represented under the net of protected areas (State Environment Protection Administration (SEPA) 2007). China's reserves are under increasing pressures from the country's dense human population. In China in 1997, there were an estimated 30 million poor people living in and around China's nature reserves (Xu and Melick 2007).

Funding is still a big problem for the reserves. Investment from governments at different levels is about 200 million yuan per year. This is merely
US $\$ 52.70$ for each square kilometer, as opposed to $\$ 2,058$ and \$157 in developed and other developing countries, respectively. As a result, $41.5 \%$ of the reserves in China are short of money to cover routine management activities ( $\mathrm{Su}$ 2004). Insufficient government funding for the operation of protected areas has resulted in increased revenue-raising activities within reserves, including tourism development and the harvesting of natural resources (Xu and Melick 2007).

Ecotourism is defined by the International Ecotourism Society (IES) as "responsible travel to natural areas that conserves the environment and improves the well-being of local people" (IES 1993). It is one of the fastest-growing sectors of the global tourism industry (Mowforth and Munt 1998). It was thought that ecotourism would have the potential to achieve conservation and community development through the provision of economic and 
social incentives to local communities, but successful cases remain scarce. Kiss (2004) pointed out that the reality is hard to evaluate because much of the information available is anecdotal and subjective. Brandon and Margoulis (1996) have also pointed out that the question of whether employment in ecotourism provides sufficient incentives for local people to safeguard natural resources can be answered only on a site-specific basis.

Nonetheless, ecotourism is booming in China. The establishment of the first national forest park (Zhangjiajie National Forest Park) in 1982 triggered the development of ecotourism. Since then, it has attracted more attention, both social and scientific, around China, and is gradually becoming an ecologically important activity in the country. According to a survey conducted by UNESCO, $80 \%$ of nature reserves in China had some kind of ecotourism program in 1997 (Chinese National Committee for Man and the Biosphere Program (CNCMB) 1998). The rapid development of the tourism industry-both domestic and overseashas led to a dramatic increase in the number of tourists visiting nature reserves and a broad use of the term "ecotourism" (Han and Zhuge 2001). Ecotourism is thought to be an inevitable way for Chinese nature reserves to achieve sustainable development (Bai 2002), and it certainly has the potential of becoming a prominent industry in western China (Liang and Cao 2006). In 2005, 1900 forest parks (mainly reserves) accommodated 180 million tourists. The number of visitors to the parks has increased annually by $20 \%$ in the past 5 years. Another change has been the increase in entrance fees for ecotourism destinations. For example, Zhangjiajie National Forest Park's entrance fee increased from 2 yuan (\$0.20) in 1982 to 240 yuan (\$30) in 2005. It is conceivable that some reserves may become economically self-supporting in this way.

The development of ecotourism in protected areas by tourism operators, often with state concessions, is a common phenomenon ( $\mathrm{Li}$ and Han 2001). The country's Nature Reserve Ordinance also does not clearly offer a provision to justify or require local participation in the decision-making process; thus, allocation of concessions to operate tourism in reserves is opaque. As the lands are effectively controlled by the government, the administrators of the reserves are the representatives of the government who manage these lands. The central government does not derive sufficient tax revenues from ecotourism to compensate for a shortage in operational funding for the reserves.

Given that ecotourism has been widely used in China's nature reserves, its role in the protection of biodiversity needs to be assessed. Does it really provide sufficient incentives for local people to safeguard natural resources? Is it appropriate to use ecotourism as a development strategy? Past research on China's nature reserves tended to focus on flora and fauna or management issues from the perspective of reserve managers and government officials (Jim and $\mathrm{Wu}$ 2002). Few quantitative studies have been conducted to specifically examine local responses toward ecotourism development in China. Previous studies of this theme revealed that local residents were optimistic about ecotourism and that ecotourism is still at an early stage in China (Stone and Wall 2003, Chen et al. 2005, Xu et al. 2006). A recent study by $\mathrm{Li}$ et al. (2006b) on Jiuzhaigou Natural Reserve affirmed it to be an example of successful tourism management, given that the natural environment was not degraded and some indicators were even improved. Does this conclusion hold true only for that particular reserve or does it also apply to other reserves in China and beyond? Evaluating the role of ecotourism in the sustainable development of local communities in and around a nature reserve with a long history of tourism can surely be instructive to other reserves in China as well.

We conducted a survey at the Changbaishan Mountain Biosphere Reserve (CMBR) to learn whether ecotourism had succeeded in achieving its objectives by assessing the attitudes of the local residents after ecotourism had been implemented for 25 years. The specific objectives of our study included: (1) to learn if local people had benefited from ecotourism; (2) to examine the extent to which ecotourism had influenced local attitudes; (3) to discuss factors that can influence local attitudes; and (4) to inform and improve nature reserve management in light of ecotourism development and associated impacts. 


\section{METHODS}

\section{Study Area}

The Changbai Mountain Biosphere Reserve (CMBR), located in Jilin Province of northeastern China [ $41^{\circ} 41^{\prime} 49^{\prime \prime}-42^{\circ} 25^{\prime} 18^{\prime \prime} \mathrm{N}, 127^{\circ} 42^{\prime} 55^{\prime \prime}-128^{\circ}$ 16'48'E], 720-2691 m above sea level (Fig. 1), is situated on the China-North Korea border and covers an area of 196456 ha. It is one of the earliest and largest natural reserves established in the country. It was upgraded to a biosphere reserve of the reserve network of the Man and Biosphere Program of UNESCO in 1980. The CMBR is rich in biodiversity: it contains 2277 species of plants and 1211 species of animals. The initial goals in establishing the reserve were to: (1) preserve several unique ecosystems of international significance, such as the temperate mixed conifer-broadleaf forests; (2) protect the habitat for Siberian tigers (Panthera tigris Linnae); and (3) preserve various endangered, rare, and other species endemic to the region. The reserve is believed to have played a critical role in biodiversity conservation in northeastern China since its establishment in 1960.

There are two townships and five state-run forest farms surrounding the CMBR. Some 150000 people living around the reserve exert great pressure on its integrity and management. Most of the peasants depend on crop farming, raising livestock, and forest products for their livelihood. They also engage in supplementary off-farm, incomegenerating activities, such as small-scale trading and wage-earning temporary jobs, or have access to remittances from family members working as migrant laborers elsewhere. Due to the rapid increase in the human population, the average household farmland in the area has decreased from 0.32 ha per capita in 1949 to less than 0.1 ha at present. All households in the village use fuelwood as a primary source of energy for domestic needs. Firewood consumption accounts for $52 \%$ of the total clearing of the forests in the region. Large-scale forest logging and consequent land change have significantly altered the ecosystem structure and function, leading to rapid loss of habitats and biodiversity in the region. By 2005, a forest army of 340 soldiers was deployed to protect forest resources. There have been severe conflicts between the local people and the Administration of Changbai Mountain Biosphere Reserve (ACMBR). This is the agency actually responsible for the management of the reserve, authorized to exist by the central government and supervised in practice by the provincial government.

Tourism in the CMBR has witnessed a steady growth since 1980 . The number of visitors increased from 29021 in 1980 to 570000 in 2005 . Since 2001, the volume of foreign visitors has exceeded 100000 per year, most of whom are South Korean, to enshrine the Baiyun peak, which is considered as the cradle of their nation. The entrance fee also increased from 2 yuan (\$0.20 U.S.) in 1980 to 225 yuan (\$28.12) in 2005, when the total income from gate fees was 22.1 million yuan (\$2.76 million) (Changbai Tourism Bureau 2006). In response to this trend, 30 ha of forest were cleared to build hotels and tourism roads inside the reserve. Meanwhile, trampling by visitors has contributed to the extinction of Ophilossum thermale, a national firstclass protected species, and the coverage of the subalpine tundra within the reserve has decreased from $30 \%$ of the land area at this elevation in 1980 to $10 \%$ today (Wang et al. 1999).

\section{Data Collection}

Erdao Township was selected for this study for three reasons. First, it is a place through which tourists travel on their way to the reserve. Second, it is located between a railway station and the reserve, and serves as a gateway community to the CMBR. Finally, surrounding the downtown area are eight villages administered by the township with a total of 4501 villagers in 1204 households. These villages are located around the reserve and along tourism roads. Thus, the likelihood of the villagers interacting with tourists and perhaps becoming involved in the industry is theoretically increased.

A survey was administered during the period from July to August 2006, and supplemented by additional survey questions in 2007. Both local villagers and business owners in the Erdao Township were targeted. Stratified sampling was employed to ensure that half the households in each administrative village were interviewed (Table 1). One adult person (older than 18 years) in each household was interviewed in his or her residence. A local farmer was hired to assist in the survey. To win the confidence of residents and to avoid potential bias, the first author was introduced to the participants and his graduate student certificate was shown to them, making it clear that the investigation was for academic research purposes without any 
affiliation to the management authority or any of the administrative apparatus of the CMBR. In addition, to avoid any influence of opinions from other members of the family, every attempt was made to conduct a private face-to-face interview with the participant.

A questionnaire with both fixed-response and openended questions was used in the study. The fixedresponse questions and alternative answers were read to interviewees, whereas the open-ended questions were asked subsequently to gain an indepth understanding of their answers. The fixedresponse questions covered six areas relating to respondents': (1) knowledge about conservation, reserve functions, and characteristics of the CMBR; (2) main household income sources; (3) perceptions of benefits and losses as a result of the development of ecotourism and the prohibitory rule against entering the CMBR; (4) attitudes toward the CMBR and ecotourism; (5) expectations and arrangements regarding the quality of life of the next generation of their household; and (6) background information (i.e., gender, education level, age, residence location, acreage of land owned, etc.).

Informal group discussions were held in the villages to probe more deeply into the perspectives and insights of local people. These were conducted in part out of concern that those villagers who had been fined or been put in prison for illegal extraction of forest products might be reluctant to express their opinions during the face-to-face interviews. Topics discussed among participants included forest resources and policies, perceptions of benefits and losses, and expectations about development and employment. During the discussion one landless farmer admitted to having been in prison and three others reported that they had engaged in brawls with the forest guards.

Five semi-structured interviews were conducted with the senior reserve director, two village leaders, and two senior officials of the forest army at the CMBR to gather detailed information about reserve management and operations, conservation measures, tourism, the communities, and local relations. Secondary information sources, such as the nature reserve official records, the overall development planning for the CMBR and the Erdao Township, as well as pertinent laws and regulations were also reviewed to develop a full understanding of the institutional environment for CMBR management. To gather contextual and supporting information, an additional 10 interviews were conducted with government tourism and environmental officials, reserve managers, academics, and researchers who were not directly associated with the CMBR. Topics discussed generally revolved around ecotourism in China, planning and management issues, the administrative structure of nature reserves, and rural community development.

\section{Data Analysis}

The variation in responses among the different groups was investigated by cross-tabulating the relevant variables and conducting a chi square $\left(\chi^{2}\right)$ test of independence. Amalgamation of rows and/ or columns of the frequency tables was sometimes necessary in order to eliminate cells with expected frequencies of less than 5 , which the $\chi^{2}$ test disallows.

Binomial logistic regression was also performed to determine whether tourism benefits, household land area, migrant labor, distance to the reserve, forest product use, awareness of prohibitory rules, and socioeconomic and demographic variables shaped people's attitudes toward the CMBR. Following Xu et al. (2006) in their study of local attitudes toward the Wolong Biosphere Reserve, the dependent variable in this study was set to 1 if the answer to the fixed-response question was "yes" or "agree" or to 0 if the answer was "no" or "disagree." It was assumed that a neutral response could indicate a potentially negative attitude (Newmark et al. 1993, Gillingham and Lee 1999). Survey data were analyzed using SPSS 12.0 at a significance level of $p<0.05$.

\section{RESULTS}

\section{Demographic Variables}

The questionnaire was administered to the local people. In total, 653 respondents -474 males (76.2\%) and 155 females $(23.8 \%)$-completed the questionnaires, and three refused (Table 1). Of these, 291 respondents were farmers who lived in the countryside and had use rights to some cropland (FWL) and 273 were farmers without cropland (FNL). Of the 89 respondents who lived in the downtown area, 34 were business owners and 55 were general workers such as shop assistants, hotel attendants, etc. The age of respondents ranged from 
Table 1. Description of the eight study villages located along the boundary of the Changbai Mountain Biosphere Reserve (CMBR)

\begin{tabular}{llllllll}
\hline \hline Village Name & $\begin{array}{l}\text { Distance } \\
\text { from reserve } \\
(\mathrm{km})\end{array}$ & $\begin{array}{l}\text { Population/ } \\
\text { households/ surveyed } \\
\text { households }\end{array}$ & \multicolumn{2}{c}{ Poor household Migrant labor $\begin{array}{l}\text { Crop land } \\
\text { (ha) }\end{array}$} & School student $\begin{array}{l}\text { Ginseng / } \\
\text { mushroom } \\
\text { (ha/bag) }\end{array}$ \\
\hline Hongfeng & 8 & $634 / 168 / 68$ & 32 & 59 & 73 & $1 / 57$ & $1.5 / 15$ \\
Toudao & 8 & $222 / 61 / 30$ & 23 & 47 & 44 & $1 / 2$ & $2.2 / 0$ \\
Xishan & 10 & $240 / 68 / 32$ & 25 & 45 & 47 & $0 / 8$ & $12 / 8$ \\
Tiebei & 2.5 & $1058 / 288 / 134$ & 60 & 300 & 3 & $1 / 130$ & $15 / 6$ \\
Baoma & 0.5 & $1186 / 286 / 145$ & 52 & 162 & 205 & $1 / 86$ & $6 / 5.6$ \\
Naitou & 4 & $225 / 72 / 32$ & 34 & 68 & 104 & $0 / 30$ & $0 / 0$ \\
Anbei & 10 & $329 / 85 / 41$ & 7 & 50 & 38 & $0 / 38$ & $0 / 0$ \\
Changbai & 11 & $616 / 176 / 82$ & 7 & 120 & 140 & $1 / 58$ & $0 / 0$ \\
TOTAL & & $4501 / 1204 / 564$ & 226 & 851 & 654 & $4 / 313$ & $36.7 / 34.6$ \\
\hline
\end{tabular}

20 to 76 , with an average of 44.2 years. Fifty-nine percent of the respondents were between 30 to 50 years old.

With respect to education, most of respondents $(62.7 \%)$ were educated to the elementary school level and the rest had graduated junior high school. In contrast, $82 \%$ of the business owners had graduated from junior high school, and $18 \%$ had graduated from senior high school or college.

With regard to the location of the respondents, the business owners and the employees in the downtown area lived in places that are $2 \mathrm{~km}$ away from the edge of the CMBR and/or the main tourism road. The distance from each of the eight villages to the CMBR ranged from 0.5 to $11 \mathrm{~km}$.

With respect to farmers' household characteristics (Table 2), most farmers do not have use rights to a large area of cropland. There are more new FNL immigrants than FWLs, and the landless farmers tend to live closer to the boundary of the reserve than do the farmers with land. Nearly three-quarters of the FNLs have family members working outside the study area. More FNLs admitted to continuing collection of mountain resources despite current prohibitions than did FWLs. Nearly $90 \%$ of farmers knew of some laws on the CMBR. There was no difference between FWLs and FNLs in household income; more than $60 \%$ of the farmers' yearly income is under 1000 yuan.

\section{Attitudes of Local People}

The attitudes of local people toward conservation of the CMBR were determined by asking two questions. First: "Generally speaking, do you think that the conservation of CMBR has brought you any advantages or disadvantages?" Interviewees were then asked: "What attitude do you hold after gauging advantages against losses?" Most of the FNLs thought that the reserve had brought only losses to them, but the FWLs perceived both benefits and losses. A significant difference was found between the attitudes of respondents and their occupations (123.4, $p<0.001)$ (Table 3). All the people in the downtown area had a positive attitude, whereas more FNLs $(81.6 \%)$ held negative attitudes than did FWLs $(60.4 \%)$. With respect to negative opinions about the reserve, most farmers attributed their dislike of the reserve to income loss due to strict 
Table 2. Farmers' household profiles and coding used in logistic regression

\begin{tabular}{lcc}
\hline \hline Variables & $\begin{array}{c}\text { Farmers with land } \\
(\%)\end{array}$ & $\begin{array}{c}\text { Farmers without land } \\
(\%)\end{array}$ \\
\hline
\end{tabular}

Household cropland

$<2 / 3$ ha $(0)$

$>2 / 3$ ha $(1)$

Length of residencys

$$
\begin{aligned}
& <10 \text { years }(1) \\
& 10-20 \text { years }(2) \\
& >20 \text { years }(3)
\end{aligned}
$$

Distance to the reserve $\mathrm{s}^{\mathrm{s}}$

$$
\begin{aligned}
& <4 \mathrm{~km}(1) \\
& 4-8 \mathrm{~km}(2)
\end{aligned}
$$

$>8 \mathrm{~km}(3)$

Migrant labors

$$
\text { No (0) }
$$

Yes (1)

Awareness of laws ${ }^{\mathrm{ns}}$

No (0)

Yes (1)

$$
\begin{gathered}
44.0(128) \\
20.0(58)
\end{gathered}
$$$$
36.0(105)
$$

$54.6(159)$

$45.4(132)$

$12.0(35)$

$88.0(256)$

Income from collection $^{\mathrm{s}}$

Yes (0)

No (1)

Household income ${ }^{\text {ns }}$

$<10000$ yuan (1)

10000-20000 yuan (2)

$>20000$ yuan (3)
$52.0(151)$

$48.0(140)$

$65.3(190)$

$22.6(66)$

$12.1(35)$
40.0 (109)

60.0 (164)

$0.0(0)$

25.9 (71)

74.1 (202)

$38.8(106)$

37.6 (103)

$23.6(64)$

$11.8(32)$

88.2 (241)

75.4 (206)

24.6 (67)

$57.6(157)$

$34.1(93)$

8.3 (23)

The sample is composed of 291 farmers with land and 273 farmers without land. Significance levels for the Chi-square Test of Independence: ns = nonsignificant, ${ }^{\mathrm{s}} P<0.001$. Numbers in parentheses refer to coding used in logistic regression.

forest use rules, crop damage by wild pigs, the restrictions on killing wild animals viewed as pests, inequitable distribution of mountain resources and their potential benefits, and inadequate attention to community development after the ban on collecting mountain resources was established.

In the same way, three questions were asked to determine respondents' attitudes toward the tourism industry. The farmers and the people living in the downtown area hold totally different attitudes toward the tourism industry (Table 4). To the question does tourism bring any benefit or any loss to you and your family, most participants in the town (88.9\% of the business owners and $50.9 \%$ of the general workers) gave a positive answer that their lives totally or partly depend on tourism, whereas few of the farmers ( $8 \%$ of the FWLs and $15.29 \%$ of 
Table 3. Attitudes of respondents toward the Changbai Mountain Biosphere Reserve (CMBR)

\begin{tabular}{|c|c|c|c|c|c|c|c|}
\hline Question & Answer & $\begin{array}{l}\text { Farmers } \\
\text { with land }\end{array}$ & $\begin{array}{l}\text { Farmers wit- } \\
\text { hout land }\end{array}$ & $\begin{array}{l}\text { Business ow- } \\
\text { ners }\end{array}$ & Employees & Chi-Square & $p$ \\
\hline \multirow{2}{*}{$\begin{array}{l}\text { 1. Have you received } \\
\text { benefits from the } \\
\text { conservation of the CMBR? }\end{array}$} & Yes & $0(0)$ & $55.3(151)$ & $100(34)$ & $74.5(41)$ & 41.628 & $<0.001$ \\
\hline & No & $100(291)$ & 44.7 (122) & $0(0)$ & $25.5(14)$ & & \\
\hline \multirow{2}{*}{$\begin{array}{l}\text { 2. Have you perceived loss } \\
\text { due to the restrictive } \\
\text { conservation of the CMBR? }\end{array}$} & Yes & $68.0(198)$ & 72.9 (199) & $0(0)$ & $0(0)$ & 115.897 & $<0.001$ \\
\hline & No & $32.0(93)$ & $27.1(74)$ & $100(34)$ & $100(55)$ & & \\
\hline \multirow{2}{*}{$\begin{array}{l}\text { 3. What attitude do you hold } \\
\text { after balancing advantages } \\
\text { with disadvantages? }\end{array}$} & Welcome & $39.6(115)$ & $18.4(40)$ & $100(34)$ & $100(55)$ & 60.105 & $<0.001$ \\
\hline & Dislike & $60.4(176)$ & $81.6(223)$ & $0(0)$ & $0(0)$ & & \\
\hline
\end{tabular}

Effective sample size is given in parentheses. All numbers are percentages of surveyed respondents. $p$ denotes level of significance.

the FNLs) believed that they benefit from it. At the same time, none of the respondents reported a loss due to ecotourism. In response to the question "Will you manage to capture the income opportunities?" fewer farmers than respondents in town expressed their willingness to get involved in tourism industry.

Concerning associations between reported income from resources extracted from within the CMBR and conservation attitudes, there was a significant inverse relationship between reported collection activities and attitudes toward conservation of CMBR $(\gamma=-0.932, p<0.001)$ : the greater the income derived from the resource extraction, the less appealing the idea of conservation of the reserve. Fifty-two percent of the FWLs and 75.4\% of the FNLs reported income from the collection of forest resources, whereas none of the business owners or the general workers identified collection of such resources as a source of income.

With respect to the relationship between awareness of pertinent prohibitory rules and conservation attitudes, there was only a marginally significant association $(\gamma=0.032, p<0.016)$ between awareness of the rules and a positive attitude toward conservation. Almost all the business owners and employees working in the Erdao downtown area, as well as most farmers (92\% of the FWLs and $86.1 \%$ of the FNLs) knew of some pertinent restrictive rules about the CMBR.

\section{Factors Influencing Respondents' Attitudes}

Two logistic regressions were conducted to determine the effects of household attributes on the probability of FWLs and FNLs being in support of the conservation of the CMBR. Each $P$-level associated with the corresponding Chi-square value was found to be significant in the two models presented, indicating acceptable model outcomes.

Model 1 focused on conservation attitudes and household attributes of farmers with some land (Table 5). On an overall basis, Model 1 accounted for $85.7 \%$ of respondents correctly classified. Nagelkerke R Square for the model was 0.831 ( $p<$ $0.001)$. The results show that for a one-unit $(4 \mathrm{~km})$ increase in distance to the reserve, the odds of being 
Table 4. Respondents' perceptions regarding the ecotourism industry

\begin{tabular}{|c|c|c|c|c|c|c|c|}
\hline Question & Answer & $\begin{array}{l}\text { Farmers } \\
\text { with land }\end{array}$ & $\begin{array}{l}\text { Farmers without } \\
\text { land }\end{array}$ & $\begin{array}{l}\text { Business o- } \\
\text { wners }\end{array}$ & Employees & Cramer & $p$ \\
\hline \multirow{2}{*}{$\begin{array}{l}\text { 1. Have you received benefits } \\
\text { from tourism? }\end{array}$} & Yes & $8.0(23)$ & $15.3(42)$ & $88.9(30)$ & $50.9(28)$ & 0.668 & $<0.001$ \\
\hline & No & $92.0(268)$ & $84.7(231)$ & $11.1(4)$ & $49.1(27)$ & & \\
\hline \multirow{2}{*}{$\begin{array}{l}\text { 2. Have you perceived loss } \\
\text { due to the tourism } \\
\text { development? }\end{array}$} & Yes & $0(0)$ & 0.07 (2) & $0(0)$ & $0(0)$ & $\mathrm{N}$ & $\mathrm{N}$ \\
\hline & No & $100(291)$ & $100(27)$ & $100(34)$ & $100(55)$ & & \\
\hline \multirow{2}{*}{$\begin{array}{l}\text { 3. Will you make some } \\
\text { preparations to take } \\
\text { advantage of the income } \\
\text { opportunities? }\end{array}$} & Yes & $3.1(9)$ & $7.6(21)$ & $100(34)$ & $81.8(45)$ & 0.681 & $<0.001$ \\
\hline & No & 96.9 (282) & $92.4(225)$ & $0(0)$ & $18.2(10)$ & & \\
\hline
\end{tabular}

Effective sample size is given in parentheses. All numbers are percentages of surveyed respondents. $p$ denotes level of significance.

in support of conservation of the reserve increased by a factor of 12.811 . For FWLs who abandoned collection of forest products in the reserve, the odds of holding positive attitudes toward conservation increased by a factor of 3.2. However, farmers holding a larger area of cropland were more likely to hold negative attitude toward conservation of the reserve $(\mathrm{OR}<1$ and $95 \% \mathrm{CI}<1)$.

Model 2 focused on the landless farmers (Table 6). Overall, Model 2 accounted for $89.3 \%$ of respondents correctly classified. Nagelkerke R Square for the model was $0.792(p<0.001)$. The results show that for FNLs who abandoned collection of forest products in the reserve, the odds of holding positive attitudes toward conservation increased by a factor of 36.512 . For each increase in household income level, the odds of family members holding positive attitudes toward conservation increased by a factor of 5.568. But an FNL living far from the reserve was more likely to hold a negative attitude (OR $<1$ and $95 \% \mathrm{CI}<1)$. For the family with a migrant laborer as a member, the odds of holding a positive attitude toward conservation of the reserve increased by a factor of 9.022 .
Household cropland, distance to the reserve, household income, length of residency, and perceived loss were significant predictors of farmers' attitudes toward conservation, but they had different effects on these attitudes. It appears that possessing use rights to cropland contributes to FWLs holding more positive attitudes toward conservation of the reserve than FNLs. However, as larger areas of cropland are subject to more damage by animals, FWLs with use rights to these lands tend to hold negative attitudes toward conservation. Although greater distance to the reserve implies less crop damage by animals for FWLs, it makes it more difficult for FNLs to take advantage of temporary job opportunities in the Erdao downtown area; thus, distance to the reserve has inverse effects on conservation attitudes for FWLs and FNLs. Although increased household income has a positive effect on conservation attitudes of FNLs, FWLs who gain more income may need more cropland, which in turn may mean more damage by animals; thus, income effects vary between the two groups. The motivation of new immigrants to move to the reserve area may be triggered by economic development in the region, not simply the forest resources; thus this group may 
Table 5. Logistic regression showing the relationship between FWLs' household attributes and favorable attitudes toward the Changbai Mountain Biosphere Reserve (CMBR) $(n=291)$

\begin{tabular}{lcccc}
\hline \hline Variable & $p$ & Exp (B) & \multicolumn{2}{c}{$95.0 \%$ CI for Exp (B) } \\
& & & Lower & Upper \\
\hline Household cropland & 0.002 & 0.121 & 0.031 & 0.466 \\
Length of residency & 0.749 & 0.890 & 0.435 & 1.818 \\
Distance to the reserve & 0.000 & 12.811 & 3.658 & 44.873 \\
Migrant labor (yes) & 0.059 & 1.717 & 0.225 & 2.284 \\
Awareness of laws (yes) & 0.882 & 1.071 & 0.431 & 2.662 \\
Income from collection (no) & 0.016 & 3.200 & 1.242 & 8.247 \\
Household income & 0.614 & 0.794 & 0.323 & 1.948 \\
Perceived tourism benefit (yes) & 0.999 & 0.557 & 0.000 & 0.330 \\
Perceived loss (no) & 0.008 & 2.533 & 1.356 & 6.016 \\
\hline
\end{tabular}

be better able to adjust to restrictive conservation laws on the CMBR. For this reason, new FNL immigrants have more positive attitudes toward conservation than do people who have lived in the area for a longer period of time.

On an overall basis, ecotourism has contributed to the realization of economic objectives in the CMBR through revenues generated by high entrance fees and a larger volume of visitors. The people in the downtown area held positive attitudes regarding conservation of the reserve and ecotourism, but most of the farmers, especially the landless farmers, did not favor conservation efforts in the CMBR. Their attitudes were more associated with factors such as amount of cropland, distance to the reserve, household income, in contrast to ecotourism toward which they tended to be indifferent. For farmers in general, therefore, ecotourism has not generated an incentive for conservation. Understanding why this is and identifying potential ways to enhance sustainable development is vital to the CMBR and other reserves in China.

\section{DISCUSSION}

\section{Conflicts over Use Rights for Forest Resources}

This study found that $50 \%$ of the farmers with land and $65.4 \%$ of farmers with no land admitted to continuing their former lifestyle, which included collecting resources from the reserve. Their negative attitudes toward conservation can be ascribed to the ban on collecting. In the survey, farmers reported that they could collect pine nuts, the main forest product in the reserve 10 years ago. This was suspended in 1996. Given that the size of the average household farm land is only 0.14 ha and thus can provide only limited food for the FWLs, the forest served as a security system: the main income source for the FWLs and essential livelihood for the FNLs. Furthermore, in the year 2000, the ACMBR issued contracts totaling 7 million yuan ( $\$ 875000)$ to private individuals to collect pine nuts. These contractors in turn hired local residents to collect the pine nuts. This entrepreneurial action generated a great deal of resentment of the ACMBR and provided local residents with an excuse to continue their collection activities. More than 100000 illegal encroachers have been recorded by the ACMBR in the past 10 
Table 6. Logistic regression showing relationship between FNLs' household attributes and favorable attitudes toward the Changbai Mountain Biosphere Reserve (CMBR) $(n=273)$

\begin{tabular}{lcccc}
\hline \hline Variable & $p$ & Exp (B) & \multicolumn{2}{c}{$95.0 \%$ CI for Exp (B) } \\
& & & Lower & Upper \\
\hline Length of residency & .039 & 1.199 & .662 & 2.172 \\
Distance to the reserve & .000 & .165 & .060 & .455 \\
Migrant labor (yes) & .029 & 9.022 & 1.258 & 34.715 \\
Awareness of laws (yes) & .495 & 1.606 & .413 & 6.253 \\
Income from collection (no) & .000 & 36.512 & 6.936 & 42.188 \\
Household income & .005 & 5.568 & 1.674 & 18.517 \\
Perceived tourism benefit (yes) & .655 & 2.081 & 2.680 & 4.461 \\
Perceived loss (no) & .014 & 3.690 & 1.297 & 10.501 \\
\hline
\end{tabular}

years. Forest products they collected include edible plants, pine nuts, mushrooms, medicinal herbs, wild honey, ginseng, firewood and tree frogs. Two illegal hunters were even caught by the forest guards in 2006, an occurrence rarely seen in the past.

This situation is not unique to the CMBR. Lack of funds is a still a problem for most reserves in China, one-third of which do not have adequate financial resources for staff salaries. To make ends meet, about $80 \%$ of the reserves have to date carried out entrepreneurial activities to exploit the resources that the reserve was set up to protect, while at the same time enforcing state regulations and laws denying local residents access to the resources. This sort of official resource exploitation has led to local people's antagonism and intensified people-park conflicts. Ouyang et al. (2002) found that there were 2017 illegal exploitation cases in 85 nature reserves from 1998 to 2000 , with one reserve having 500 cases, the highest among all surveyed.

In China, it has been said that "those living on a mountain get their living from the mountain," and many local people have an ingrained traditional belief that it is natural to get various kinds resources from the environment. Since 1975, the World Conservation Union (IUCN) and World Parks
Congress have been making important statements implying recognition of the rights of indigenous peoples and the need to accommodate these rights in protected areas. This suggests that the government in China should protect and encourage customary use of biological resources in accordance with traditional cultural practices that are compatible with conservation and sustainable resource use.

\section{Legal Issues}

The aforementioned problems are magnified by the legal and jurisdictional environment surrounding nature reserves in China. The nature resources of the protected and scenic areas of China belong to the Chinese people according to the Chinese constitution. Hence, they can be regarded as "state property" owned by the central government. The national resources are managed through authorizations on many levels, from the central government down to the county governments in specific regions. When a national reserve is created and the land is designed as a protected area, local residents who have used the land are not compensated as in a land sale, because, although they are users, they have never possessed property rights in the sense of actually 
"owning" the land. In the newly created arrangements, an administrative unit is given the authority to manage the reserve and in effect becomes the one and only legitimate representative of the nation to exert ownership. In the process, it effectively monopolizes the benefits of the natural resources found in the reserve.

The management of the CMBR is legally supported by three sets of regulations: the Regulations of the People's Republic of China on Nature Reserves (RPRCNC) (State Council 1994); the Regulations of the People's Republic of China on Wildlife (RPRCW) (Forest Administration 1994); and the ad hoc regulation on CMBR (AHRC) (Jilin province government 1988). With respect to the administration of reserve areas in general and the allocation of benefits derived from them, the RPRCNC states that the managing department should deal with the relationship between conservation and local economic development and local livelihoods. This is obscure and hard to act on. Other directives, such as articles 26-28 and 32-35, restrict the actions of local residents, but no articles exist to deal with the losses endured by local residents and/or related compensation. The RPRCW, the principal rule on standards for evaluating illegal criminal activities involving wildlife and pertinent punitive measures, contains nothing about such compensatory aspects. The AHRC identifies recipients of tourism benefits in general and more specially, beneficiaries from the construction of tourism facilities:

\section{The tourism benefits belong to the ACMBR and should be put toward conservation activities. Commercial tourism facilities can be constructed inside the reserve and owned by the ACMBR; or be constructed in cooperation with other enterprises and they can share the benefits proportionately to their investment; or by enterprises solely if authorized by the provincial forestry bureau and shall pay $0.5 \%$ of its revenues to the $A C M B R$.}

Articles 5 and 6 also make it clear that it is forbidden to hunt, log, graze, or mine in the reserve; any illegal actions will be punished as described in article 19. However, there is no article on the rights of local people or their role in the management of the CMBR.

In order to conserve the wildlife in the reserve, two measures have been employed since the year 2000: an enhanced publicity strategy for local residents and stronger punishments for illegal extractions. Organized meetings, leaflets, and TV programs have been used frequently to provide pertinent information to local people; meanwhile, all 340 forest guards patrol the reserve boundary day and night during the harvest season. It is worth noting that awareness of the rules is one factor contributing to attitudes of farmers who disdained conservation efforts in the reserve. Generally, the respondent cited punishment warnings such as anyone taking one tree frog illegally will be fined 500 yuan $(\$ 40)$ and for taking 10 frogs, will be sent to jail for 1 year, no entering the reserve, or for logging one pine, one can be sentenced to prison for 3 years.

Whereas international law recognizes that indigenous peoples have rights to own, manage, and control their lands and conservation policies have accepted this in principle (Colchester 2004), it is now widely recognized that the exclusion of indigenous peoples and other local communities from protected areas can also undermine conservation objectives for such areas by creating conflicts between local people and managing departments. Tourism planning needs to involve both local communities and multi-government agencies in mechanisms for sharing and distributing benefits from the reserves. Financial incentives should be available to those who are most adversely affected by conservation management activities.

\section{Conservation Attitudes and Ecotourism}

Ecotourism has not affected the local farmers' livelihoods, either in the form of direct benefits or losses, and their attitudes toward it can be interpreted as either indifference or disappointment, given that few have benefited or become involved. Their attitudes were unknown in 1980s and throughout much of the 1990s. A survey conducted in 1997 by Wang et al. (2000) revealed that the $83.6 \%$ of local residents supported tourism industry development and $63.8 \%$ expected that their villages would become sightseeing sites that would attract tourists. These attitudes were consistent with other case studies in China. Ecotourism has been enthusiastically welcomed by local people since it was introduced to China. Stone and Wall (2003) pointed out that ecotourism was in its early stages of development in two forest parks in Hainan province and that most officials and residents were confident that tourism growth would eventually generate benefits for their community. Jim (2003) 
found similar results at a newly established provincial nature reserve in Guangdong province. Indeed, limited benefits, optimism, and positive attitudes are characteristic stages of ecotourism development (Doxey 1976, Butler 1980, D'Amore 1983). But how do people become indifferent to it after 25 years have passed?

First and foremost, this outcome stems from the process of establishing and managing nature reserves in China, in which only experts (biologists, geographers, reserve managers, local and central government officers) were actively involved (Han and Zhuge 2001). The top-down process has generally paid insufficient attention to the significant role of local participation in planning, management, and decision making for the reserves (Jim and Xu 2002). This effectively precludes local residents from sharing any of the decision-making power relative to ecotourism development plans (Xu et al. 2006). Not surprisingly, expectations that villages would aid in and benefit from attracting tourists have not been realized.

Secondly, opportunities for farmers in the study area to benefit from ecotourism are slim. Here, ecotourists are primarily East Asians who differ significantly from European and North American ecotourists. They are attracted to vegetation and geology more than charismatic megafauna, and have a strong aesthetic and philosophical relation to these attractions, all of which fits well within a disciplined group dynamic (Weaver and Lawton 2007). Tourism in the CMBR consists of a variety of 1-day sightseeing tours; thus, the length of stay at the reserve is no more than 1 day. In addition, visitors do not stop in any community en route to the reserve; thus, there is limited chance for the villagers to interact with the tourists. Moreover, the tourism period extends for only 4 months (from July to October). During the survey period, only one female participant peddling souvenirs on the tourism road was found. A respondent reported that a family restaurant in Tiebei village had opened in 2003 but failed within a couple of weeks, because few visitors patronized the establishment.

Finally, local people lack the financial and human capital to invest in ecotourism and have only their labor to sell to the tourism industry. With respect to the surveyed villages, a quarter of the households (240) are ranked as extremely poor, for family members' average yearly income in 2005 was less than 996 yuan $(\$ 124)$; and in this same year, the average yearly income for a farmer in China was 3325 yuan (\$416) per capita at the national level (State Statistical Bureau (SSB) 2006). This makes it impossible for local farmers to invest in beneficial tourism businesses concentrated in the downtown area or at the gate of the reserve where visitors make their stops. In their study on Jiuzhaigou, Li et al. (2006b) stated that local benefits are obtained mostly from family hotels, souvenir shops, and renting special props for taking photos to visitors, etc., but these were rarely found in the villages surveyed.

In this light, ecotourism dose not necessarily automatically imply benefits for local people. Of the reserves that have developed tourism, in 1997, only $10.7 \%$ were providing some benefit to more than half of the local families and about $22.7 \%$ did not produce any economic benefits for local communities (CNCMB 1998).

Park establishment alters the local economic base and has often resulted in reduced access to resources for local people (Lindberg et al. 1996). Earmarking a portion of tourism revenues or the park's budget to provide small business loans for local people who wish to start a tourism venture may be an effective way to help generate and retain community benefits (Lindberg 1991). The sharing of revenues with local residents has become part of public policy in some countries. For example, Zimbabwe has formed a relatively solid institutional framework, Uganda enacted a National Wildlife Policy, and Nepal has also been supporting wildlife tourism as a source of revenue that can be shared with local communities. This is especially important because many of the threats protected areas face arise from the needs of local communities to use resources to survive (Norris 1992). There is no doubt that the farmers here have to make a living by using the forest resources, and some compensation in the form of direct revenues or guaranteed opportunities for employment in ecotourism are essential to their survival as well as for engendering their support.

\section{Opportunities for Conservation}

Despite the difficulties discussed above, there are a number of positive actions and events that have occurred over the past 3 years that warrant a cautious optimism regarding future conservation efforts in China, including the role of ecotourism. 
Both central and local governments have taken steps to improve nature reserve management in China. A specific code stipulating the role of the management agency was established by the central government in 2006; it prescribes that the natural resources, the relationship to the local people, and tourism development should all be assessed and supervised on a regular basis. This rule also terminated the contracting out of pine nut collecting in the CMBR. A Jilin provincial ordinance regarding compensation to farmers for damage caused by nationally protected animals was approved in 2003. These measures can be helpful in alleviating the aforementioned conflicts to some degree.

Moreover, in 2006, an independent administrative management committee was set up to take the place of the jurisdictionally awkward Administration of Changbai Mountain Biosphere Reserve (ACMBR), and the administrative region was also enlarged to include not only the reserve area, but also its neighboring villages and towns. The ultimate goal of the newly formed committee is to help bring about ecologically sustainable economic development.

At the same time, there is a broad willingness among all the people here to cooperate regarding conservation. Everyone shares one common sentiment: "we all live our lives by the mountain; no one can live without the forest, so we have to protect it for ourselves and for the next generation." Although most of the farmers revealed an unwillingness to obey restrictive rules against entering the CMBR, many would seem to have no choice as it is necessary for making a living. They too are in fact worrying about the overexploitation of valuable plants and wildlife. For example, wild ginseng, one of the famous three treasures in northeastern China, and a national first-class protected species, was one of the main forest products in the Changbai Mountain region before the 1950s. This rare species is hardly found in the forest now. So farmers have indeed realized that conservation is essential to their livelihoods.

The CMBR is rich in valuable herbs; it has 913 plant species classified as Chinese medicinal herbs. The cultivation of valuable herbs such as ginseng and edible wild vegetables has successfully led some families to totally abandon collection activities. Throughout this investigation, it was evident that people in the area are longing for useful knowledge and technology to improve their living conditions and that if one type of moneymaking mode proves effective, it can spread very quickly in and around the area. We found successful alternatives among the villages to include the cultivation of ginseng and mushroom, as well as raising honey bees and tree frogs. This suggests that the government should pay more attention to providing vocational trainingespecially that related to planting techniques-to local people to foster family economic development.

Migrant labor can provide another potential pathway to conservation. Logistic regression results (Tables 5 and 6) indicated that household migrant labor significantly influenced the attitudes of landless farmers, and this trend can also be found for the FWLs. These results were rather encouraging. According to a survey by China's State Statistical Bureau, migrant laborers earn an average monthly salary of 966 yuan $(\$ 120.75)$, which is about four times the average farmer's income. This study found that migrant laborers can strongly affect the conservation attitudes of their family members by supporting them with income that concurrently relieves their need to extract resources from the reserve. Migration also directly relieves some of the immediate pressures on the reserve resulting from local population numbers. Our findings in this research are consistent with those of other researchers. Li et al. (2006a) pointed out that migration (especially for the purpose of higher education) is an ecologically effective, economically efficient, and socially acceptable approach to conserving wildlife habitat or biodiversity.

At the same time, it is important to provide younger local residents not inclined to migrate with some tourism-related job opportunities. One option, for example, would be for the government to establish a standard for having a certain percentage of local labor for hotel businesses and tourism operations.

\section{IMPLICATIONS}

According to current standards, the CMBR cannot as yet be considered as a successfully operating ecotourism destination-it generates funds for conservation, but community benefits are very limited. Community members remain indifferent to the tourism industry and continue to extract forest products from the reserve. The farmers' indifferent attitudes highlight the fact that the CMBR has lacked the necessary institutional capacity to 
provide substantive benefits to local communities. But cooperation and support from local communities is considered essential to the management of protected areas (Wells and Brandon 1992, Gurung 1995, Mehta and Heinen 2001, Colchester 2004). A new, more comprehensive policy and legislative package for ecotourism and resource use should be formulated to ensure that local people can share in the benefits generated by these activities, including being guaranteed a reasonable proportion of the income derived from them.

The location of the people shapes their attitudes toward conservation. This situation presents another challenge for the reserve management. If only the people living downtown can benefit, the forests will still suffer, and, therefore, the effectiveness of ecotourism will be greatly diminished. Poor farmers are often less capable of capturing benefits resulting from development efforts, and will have no choice but to continue extracting a living from the reserve. Ecotourism plans should be designed with a focus on the villages and taking economic differences into consideration; then they can win substantial support from the local population. Meanwhile, its effectiveness has to be compared with other solutions such as cash-crop cultivation, etc.

The examination of local responses toward nature conservation and the ecotourism industry, including attitudes, and expectations, can produce valuable information that can be incorporated into the decision-making process and help to alleviate people-park conflicts. The findings indicate that most farmers did not have a positive attitude toward conservation and most were indifferent to the tourism industry. Understanding why and how this is so can help reserve managers better understand ecotourism, improve protected area management, and integrate this information into pertinent policymaking processes. It is hoped that this study will provide useful information necessary to create a potentially nationwide ecotourism development strategy.

Responses to this article can be read online at: http://www.ecologyandsociety.org/voll3/iss2/art55/responses/

\section{Acknowledgments:}

This research was financially supported by the National Key Technologies R\&D Program of China (2006BAD03A09), National Natural Science Foundation of China (NSFC40873067\&30871958), and the 863 Program (2006AA10Z251). We would like to thank the Administration of Changbai Biosphere Reserve, the Changbaishan Tourism Bureau, the government of Erdao Township, and the indigenous people in the study area for their help during our interviews and field surveys.

\section{LITERATURE CITED}

Bai, L. 2002. Ecotourism and the development of China's natural reserves. Journal of Social Science of Yunnan University 26:20-25. (In Chinese.)

Brandon, K., and R. Margoulis. 1996. The bottom line: getting biodiversity conservation back into ecotourism. Pages 28-38 in J. A. Miller and E. Malek-Zadeh, editors. The ecotourism equation: measuring the impacts. Yale Bulletin Series, No. 99, Yale University, New Haven, Connecticut, USA.

Butler, R. W. 1980. The concept of a tourist area cycle of evolution: implications for management of resources. The Canadian Geographer 24:5-12.

Changbai Tourism Bureau. 2006. Record of number of visitors annually. Unppublished document.

Chen, Z., J. Yang, and Z. Xie. 2005. Economic development of local communities and biodiversity conservation: a case study from Shennongjia National Nature Reserve, China. Biodiversity and Conservation 14:2095-2108.

Chinese National Committee for Man and the Biosphere Program (CNCMB). 1998. Nature reserves and ecotourism. Science and Technology Press of China, Beijing, China. (In Chinese.)

Colchester, M. 2004. Conservation policy and indigenous peoples. Environmental Science and Policy 7:145-153. 
D'Amore, L. J. 1983. Guidelines to planning in harmony with the host community. Pages 135-159 in P. E. Murphy, editor. Tourism in Canada: selected issues and options. University of Victoria, Victoria, British Columbia, Canada.

Forest Administration. 1994. Regulations of the People's Republic of China on wildlife conservation. Chinese Forestry Press, Beijing, China. (In Chinese.)

Doxey, G. V. 1976. When enough's enough: the natives are restless in old Niagara. Heritage Canada 2:26-29.

Gillingham, S., and P. C. Lee. 1999. The impact of wildlife related benefits on the conservation attitude of local people around the Selo game reserve, Tanzania. Environmental Conservation 26:218-228.

Gurung, C. P. 1995. People and their participation: new approaches to resolving conflicts and promoting cooperation. Pages 223-233 in J. M. McNeely, editor. Expanding partnerships in conservation. Island Press, Washington, D.C., USA.

Han, N. Y., and R. Zhuge. 2001. Ecotourism in China's nature reserves: opportunities and challenges. Journal of Sustainable Tourism 9:228242.

International Ecotourism Society (IES). 1993. Ecotourism guidelines for nature tour operators. The International Ecotourism Society, Washington, D.C., USA.

Jilin Province Government. 1988. The ad hoc regulation on Changbai Mountain Biosphere Reserve. The Jilin Province People Press, Jilin, China. (In Chinese.)

Jim, C. Y., and S. S. W. Xu. 2002. Stifled stakeholders and subdued participation: interpreting local responses toward Shimentai Nature Reserve in South China. Environmental Management 30:327-341.

Kiss, A. 2004. Is community-based ecotourism a good use of biodiversity conservation funds? Trends in Ecology and Evolution 19:232-237.

Li, A., G. M. He, Z. Liang, and J. Liu. 2006a. Impacts of demographic and socioeconomic factors on spatio-temporal dynamics of panda habitat. Biodiversity and Conservation 15:2343-2363.

Li, W., and N. Han. 2001. Ecotourism management in China's nature reserves. Ambio 30:62-63.

Li, W., Q. Zhang, C. Y. Liu, and Q. F. Xue. 2006 b. Tourism's impacts on natural resources: a positive case from China. Environmental Management 38:572-579.

Liang,L. K., and X. Cao. 2006. On the ecotourism in our nature reserves. Ecological Economy 2:120123. (In Chinese.)

Lindberg, K. 1991. Policies for maximizing nature tourism's ecological and economic benefits. World Resources Institute, Washington, D.C., USA.

Lindberg, K., J. Enriquez, and K. Sproule. 1996. Ecotourism questioned: case studies from Belize. Annals of Tourism Research 23:543-562.

Mehta, J., and J. Heinen. 2001. Does communitybased conservation shape favorable attitudes among locals? An empirical study from Nepal. Environmental Management 28:165-177.

Miao, H. 2000. Community participation mechanism of China's nature reserve. Pages 57-71 in China Man and Biosphere Committee, editor. Policy study on sustainable management for China's nature reserves. Scientific and Technical Documents Publishing House, Beijing, China. (In Chinese.)

Mowforth, M., and I. Munt. 1998. Tourism and sustainability: new tourism in the third world. Routledge, London, UK.

Newmark, W. D., N. L. Leonard, H. I. Sariko, and D. G. M. Gamassa. 1993. Conservation attitudes of local people living adjacent to five protected areas in Tanzania. Biological Conservation 63: $177-183$.

Norris, R. 1992. Can ecotourism save natural areas? National Parks 1: 33-34.

Ouyang, Z., X. Wang, H. Miao, and L. Y. Han. 2002. Problems of management system of China's nature preservation zones and their solutions. Science and Technology Review 1:49-56. (In chinese.) 
State Council. 1994. Regulations of the People's Republic of China on nature reserves. State Environmental Protection Administration, Beijing, China. (In Chinese.)

State Environment Protection Administration (SEPA). 2007. China environment bulletin of 2006. China Environment Publishing House, Beijing, China. (In Chinese.)

State Statistical Bureau (SSB). 2006. China statistical yearbook 18. China Statistical Publishing House, Beijing, China. (In Chinese.)

Stone, M., and G. Wall. 2003. Ecotourism and community development: case studies from Hainan, China. Environmental Management 33(1):12-24.

Su, Y. 2004. Countermeasures for improving management of nature reserves in China. Science and Technology Review 9:31-34. (In Chinese.)

Wang, X. L., R. Z. Che, and Y. X. Huang. 1999. Environmental impacts of tourism in the Changbaishan Biosphere Reserve, Northeast China. Chinese Journal of Ecology 18(3):46-53.

Wang, X. L., Z. Q. Hao, and D. N. Xiao. 2000. Ecotourism development and natural forest protection in Changbai Mountain Nature Reserve. Pages 419-426 in P. C. Zhang and Q. L. Wang, editors. Analects of specialists' point of views on natural forest protection project. Forestry Press, Beijing, China. (In Chinese.)

Weaver, D. B., and L. J. Lawton. 2007. Twenty years on: the state of contemporary ecotourism research. Tourism Management 28(5):1168-1179.

Wells, M. P., and K. B. Brandon.1992. People and parks: linking protected area management with local communities. World Bank, Washington, D.C., USA.

Xu, J., E. T. Ma, D. Tashi, Y. Fu, Z. Lu, and D. Melick. 2005. Integrating sacred knowledge for conservation: cultures and landscapes in southwest China. Ecology and Society 10(2): 7. [online] URL: http://www.ecologyandsociety.org/vol10/iss $2 / \operatorname{art} 7 /$

Xu, J., and D. R. Melick. 2007. Rethinking the effectiveness of public protected areas in southwestern China. Environmental Management 21:318-328.
Xu, J. Y., L. D. Chen, Y. H. Lu, and B. J. Fu. 2006. Local people's perceptions as decision support for protected area management in Wolong Biosphere Reserve, China. Journal of Environmental Management 78:362-372. 